\title{
Integrated Farming Approaches for Doubling the Income of Small and Marginal Farmers
}

\author{
M. Goverdhan, Md. Latheef Pasha*, S. Sridevi and Ch. Pragathi Kumari
}

AICRP on Integrated Farming Systems, Professor Jayashankar Telangana State Agricultural University, Rajendranagar, Hyderabad -500 030, Telangana, India

*Corresponding author

K e y w o r d s
Integrated farming
systems, Rice, Maize,
Livestock, Net return,
Employment

\section{Introduction}

After attaining independence and subsequent efforts made through green and other revolutions, the country has got ability to produce 5 times more food grains, 9 times horticultural crops, 9.5 times milk production and 12 times fish production per annum as seen in terms of maintaining $>60 \mathrm{M} \mathrm{t}$ buffer stock for any uncertainty and emergencies. Yet FAO states that 194.6 M people accounting a quarter of the undernourished population in the world are in India (The State of Food Insecurity in the World, 2015). Increased food production with his relentless efforts for past 50 years for burgeoning population not made farmer to lead a comfortable and respectable life due to more dependency on crop centric enterprises since two decades, changing climate, increased cost of production, low output price due to market mania put him into debt traps and finally taking their lives.

Aiming for more and more production farmers shovelled heavily all soil plant nutrients which 
are seldom replenished. Nitrogen is universal deficit in almost $90 \%$ of the soils. Phosphorous deficiency is also wide spread in $80 \%$ of the soils and $60 \%$ are deficient in potassium. Sulphur deficiency is spread on $75 \%$ of the soils. The micro nutrient deficiencies are also widely recognised with time. It is estimated that nearly $50 \%$ of the sampled soils are deficient in $\mathrm{Zn}, 20 \%$ in B, $18 \%$ in $\mathrm{Mo}, 12 \%$ in $\mathrm{Fe}$ and $5 \%$ in $\mathrm{Cu}$. This is a threatening situation. The response ratio or the factor productivity estimates are that $15 \mathrm{~kg}$ food grain was produced per $\mathrm{kg}$ fertilisers including NPK in 1974-79 is dropped down to $6 \mathrm{~kg}$ in 2010-11 forcing to use 2.5 to 3 times more fertiliser to obtain the same yield 40 years ago.

Cultivated area (142 m ha) is fixed or hardly any scope to increase (Gill et al., 2005). The said total area is being cultivated by 129.2 million land holders who are mostly $(85 \%)$ small and marginal farmers. Cultivation of cereals, pulses alone in diminished farm size neither providing sufficient employment nor remunerative family income. It is thus, $40 \%$ of the farmers opted out to leave agriculture, if they be given other jobs. Increased risk, cost of cultivation, low productivity and market price urging the farmer to take such hasty decisions.

Integrated Farming System approach which works on small and marginal land holdings with the principle that waste or refuse of one organism (enterprise) is feed for other (Faroda et al., 1978 and Tomer et al., 1982) offers profused employment, regular production and income besides reducing production risks, cost of cultivation through optimal use of natural resources and internal resource recycling (Singh et al., 1993 and Singh et al., 1997).

Integrated Farming system demands multiple tasks in production and marketing. Therefore rural educated youth who intuitionistic in operating smart phones and ICT tools be attracted in ease of doing marketing and realising premium price to their produce.

This is the epilogue that prompted the authors to initiate the model of Integrated Farming Systems to ascertain how this approach outweighs the largely adapted practice of growing a crop or cropping system in terms of in situ resource utilisation saving considerable expenditure on input costs and achieving diversified stuffs for the livelihood of small and marginal farmers, their animals and birds while gaining a continuous flow of cash for family needs.

\section{Materials and Methods}

The model initiated during kharif 2015 occupied in 1.0 ha of land typical to majority of the peasants in Telangana. It is divided into 5 blocks. The first block is for cropping system involving rice-sweet corn- dhaincha on 0.24 ha. The variety of rice was RNR 15048 . Sweet corn cultivar Sugar 75 was grown at $60 \times 20 \mathrm{~cm}$ spacing. A total of $18,000 \mathrm{cobs}$ were harvested. Dhaincha was grown with 10 $\mathrm{kg}$ seed. The heavy seed rate was to occasionally collect the foliage of this legume as green fodder until it was incorporated in the soil in situ at flowering stage of the crop. The second block was grown with banana variety Grand 9 on 15 July 2015 at a spacing of $1.8 \mathrm{x}$ $1.8 \mathrm{~m}$ with 472 plants for fruits on $0.152 \mathrm{ha}$. It bears the fruits after one year. Purpose fully the sowing date is opted as to avoid production in the month of May during which markets will be glutted by most preferred mango.

The $3^{\text {rd }}$ block is grown with brinjal-tomato cropping system on 0.2 ha for vegetable production. The variety of brinjal was Shyamala and the tomato hybrid was Vishwanathan. High potential brinjal out yields upto November and tomato hybrid 
vishwanathan is a creepy suitable for staking and summer off season. Thus a total of 0.6 ha is allocated to food grain, fruit and vegetable crops vis-a-vis crop residues for feed and composting. The saplings of coconut variety Godavari Ganga are planted all around the 500 running metere bunds at a distance of $7.5 \mathrm{~m}$ or $25 \mathrm{ft}$. There are 50 plants. Single pole, single row pandal was made in between coconut plants to grow field beans, bitter gourd, bottle gourd etc. Pandal admeasuring $400 \mathrm{~m}^{2}$ or 4300 sq $\mathrm{ft}$ i.e. 0.04 ha was built in front of cattle shed. Field beans and gourds were grown in order to get economic yield and shade to poultry birds during day time. One or two feeders and water tubs were also arranged for supplemental feed to birds.

\section{Fodders}

Details of the fodders grown are presented in table 1. All sowings were done in kharif. Sorghum fodder multi cut cultivar CSH 24 $\mathrm{MF}$ and maize fodder cultivar African tall were grown each in an area of 0.12 ha to meet instant green fodder requirement. Simultaneously, high yielding multi cut CO-4 and CO-5 were planted each in 0.06 ha. Legume perennial fodder Lucerne is also grown in 0.12 ha to meet protein diet of animals. Hay @ 2t produced in 0.24 ha paddy was used as dry fodder. Similarly sweet corn green fodder @ 6t obtained during rabi after rice was fed to all animals.

\section{Shed for livestock}

Live stock type and size is decided based on local demand, capital investment suitable to small farmer and manageable levels by family labour. It is thus, planned to house 4 buffaloes, 4 calves, ram lambs 2 batches of 10 in each, $30+4$ rabbits, $100+4$ desi poultry birds and quail birds 7 batches of 1000 in each batch. Accordingly, a low cost shed was constructed in an area of $1875 \mathrm{sq} \mathrm{ft}(75 \times 25 \mathrm{ft})$ or $0.016 \mathrm{ha}$, comprising 7 compartments admeasuring 11x $25 \mathrm{ft}$ each having required amenities to respective livestock/birds. Farm family is housed in one compartment to have round the clock security and attendance. A cement concrete channel is made in slope in front of shed with a view to collect urine of livestock /shed wastes. Another pit measuring $2 \times 2 \times 3 \mathrm{~m}$ was dug at the corner of the cattle shed and the said concrete cement channel is connected to collect about 250-300 1 of shed wastes every day. This water was used to make jeevamrutham/Ganamrutham after proper filtration or else was pumped to compost pit for enrichment.

\section{Quails}

The low fat, high protein white meat of these Japanese birds is a delicacy and pleasure to eat for its taste. The birds grow well in a cool and warm weather. They are robust to diseases and do not require any vaccination. Nevertheless, intensive baby care is required for initial 15 days. Hence 4 brooders are provided with lamps to provide energy and warmth. Day old chicks@1000 to each batch were purchased for Rs 6 per chick. Feed was supplied as per recommendation and birds were grown till they attain 160-180 $\mathrm{g}$ or for 30 days whichever is earlier. They were sold @ Rs 27 per bird.

\section{Hens}

Country bird meat and egg is known for its foremost delicious dish and thus fetches premium price. They are omnivorous. Selected 100 pullets and 10 roosters housed in $275 \mathrm{sq} \mathrm{ft}$ chamber and reared as semi intensive method. Hens coetus gave on an average 15 eggs per day where in the graded, best sized un broken were incubated through artificial incubators to obtain $>80 \%$ hatching and allowed hen for early crossing and egg laying. Early aged (30 days) chicks were nurtured with baby care duly supplementing chick feed 
and administering recommended vaccinations. Afterwards, they were allowed to main flock for natural/semi intensive feeding. Bird attained marketable size $(1 \mathrm{~kg})$ in 120 days by consuming $4 \mathrm{~kg}$ feed. Lucerne fodder and rice bran amalgamated azolla waste also fed to the flock@ $5 \mathrm{~kg}$ and $1 \mathrm{~kg}$ per day respectively.

\section{Rabbits}

Rearing of rabbits is a good hobby and potential source of income to the farmers dwelling in areas in the vicinity of towns for a comfortable market. Suitable and recommended New Zealand white breed was selected for the study. They feed lot of greens, farm waste, vegetables and grains. The formulation of feed requires the ingredients of feed formulated as per recommendation. A female rabbit on an average lays 8-10 kits. It has 8-10 teats to milk them. A rabbit eats about $3 \mathrm{~kg}$ concentrate feed from birth to market. A 24 does, 4 bucks are accommodated in the shed.

\section{Sheep}

Another portion admeasuring $25 \times 11 \mathrm{ft}$ in the shed is used for the stay and feeding to ram lambs. Two months old, mother feed oblivious ram lambs of Nellore brown breed were purposefully purchased from local market to avoid infant mortality and breast feeding risks. They were put on plat farm system made at the height of 5' and were completely stall fed by CO-4 and lucerne green fodders @ $2 \mathrm{~kg}$ and $1 \mathrm{~kg}$ respectively per day. Every animal is treated with PPR vaccination, de worming and liver tonic as a measure to prevent diseases.

\section{Dairy}

Murrah buffaloes are well adapted to the Telangana state. Four just calved animals were purchased in two batches at the interval of 6 months in order to have continuous milk and returns. They were given dry, green fodder and concentrate feed as recommended.

\section{Rice-maize sequence under conventional system}

Rice-Maize cropping system was compared with IFS model as it is a predominant cropping system in irrigated dry situation of Southern Telanagna. Rice variety RNR 15048 was sown during July $2^{\text {nd }}$ week and transplanted 25 days later. Crop was harvested after attaining 120 days duration. Maize cultivar $30 \mathrm{~V} 92$ a private hybrid was sown under conventional tillage after kharif rice harvest. Rice-maize sequence, management practices were done as per recommendation. Grain and economic yield of all components were recorded and gross and net returns were realised based on market price of produce and cost of crop and live stock production.

\section{Results and Discussion}

\section{Crop production and income}

The yield of crops, expenditure incurred and the profits earned are shown in table 1. Rice cultivated in kharif on 0.24 ha land produced $1.6 \mathrm{t}$ grains and $2 \mathrm{t}$ straw. The straw was used as cattle feed. The cultivation expenditure was Rs.6,000. The grain sold @ Rs 15000 per ton fetched Rs.24,000. The net income was Rs.18,000. The market value of 2 tons hay was Rs.2,000. The hidden value rose further through the increase in milk and meat production of the buffaloes. The production of 18,000 sweet corn cobs by the sequence crop of maize valued at Rs 3 each earned Rs 54,000 . The cost of cultivation of this crop was Rs.24,000. The net profit was Rs.30,000. In the summer season dhaincha was grown as green manure to improve the soil. Part of the growing crop was fed to the animals as protein rich green fodder until it was incorporated in the soil. Banana cultivated with an 
expenditure of Rs.16,600 on 0.15 ha yielded 11.5 ton hands valued at Rs 5000 per ton. The sale of fruits accrued a gross return of Rs.57,500 and net profit of Rs.40,900.

The vegetable crops brinjal and tomato were grown in sequence on 0.2 ha in kharif and rabi. The cost of cultivation of brinjal was $\mathrm{Rs}$ 10,000 . The yield was 2.0 tons. Gross income of Rs.24,000 was realised at a sale price of Rs 12000 per ton. The net profit was Rs.14,000. From the same piece of land tomatoes grown in rabi produced 2.0 ton berries with an expenditure of Rs.20,000. The fruits sold at Rs.20000 a ton in the market. The gross value of the produce was Rs.40,000 and the net profit was Rs.20,000. Net profit of Rs.15,000 was realised from the field beans grown on the bunds.

The vegetables erected on pandals viz., bottle gourd fetched a cash benefit of Rs 1,500 and bitter gourds Rs 3950. Twenty plants of drum stick grown around the shed produced an average of 20 pods per plant. They fetched a profit of Rs.800 when sold @ Rs.2 each. Thus a range of crops were produced from a total of 0.6 ha throughout the year providing food, fodder, green manure, vegetables and fruits with earnings of cash at different times.

\section{Fodder production}

Green fodder yield of $24 \mathrm{t}$ was harvested throughout the year (Table 1). Perennial green fodder leguminous crop lucerne was grown on 0.12 ha in the cold season during winter. The forage yield was 20t per year. These are the highly nutritious and palatable fodder. The crop residues obtained from rice-sweet corn were additional. Rice produced $2 t$ hay. Sweet corn grown in staggered sowings produced $6 \mathrm{t}$ stover at the time of harvest of cobs. The moisture content was about $50 \%$ in the stover. This is equivalent to $2 \mathrm{t}$ dry stover with $15 \%$ moisture or $24 \mathrm{t}$ green fodder with $75-80 \%$ moisture. The total harvest of roughage was $2 t$ dry and $44 \mathrm{t}$ green fodder in the entire year from different sources (Table 1). This was enough to meet the requirement of green and dry fodders for the animals maintained in the model. The production of legumes was $20 \mathrm{t}$.

\section{Cost of production and income from livestock}

\section{Quails}

Day old chicks were purchased @ Rs.6 each. Total expenses therefore were for 48000 for 8000 day old chicks for 8 batches per year (Table 2). Quails attain live weight of 160-180 grams in 35 days and are ready for marketing. During this period each bird eats 600 grams feed that costs Rs 20 per $\mathrm{kg}$ and Rs 12.00 per bird. For 8 batches the cost of feed is (Rs.12 per bird and for 8,000 birds) Rs. 96,000 in a year. Eight crops of quails were sold one after another in one year at the rate of Rs.27 per bird. The selling price per bird is Rs.27.

The gross income from each crop and eight batches were Rs.27,000 and Rs 2,16,000 respectively. The cost of production was Rs.18,000 per each crop and Rs 1,44,000 from eight batches. The net profit was Rs.9,000 and Rs 72,000 per crop of quails and per year respectively.

\section{Hens}

The hens reach marketable size and attain a weight of $1 \mathrm{~kg}$ in 4-5 months. They sell at Rs 200 per kg live weight (Table 2). The initial cost of hens is Rs 300/bird and 33000 for 100 hens and 10 cocks birds. The cost of feed grade is Rs $20 / \mathrm{kg}$. The cost of $4 \mathrm{t}$ feed is Rs 80,000 per year. At the end of the year, the gross income, cost of cultivation and net income was Rs.2,00,000, Rs.1,13,000 and Rs.87,000 respectively. 
Table.1 Production of food and forage crops and income from IFS unit and conventional system

\begin{tabular}{|c|c|c|c|c|c|c|}
\hline \multirow[t]{2}{*}{ Sl.No } & \multirow{2}{*}{$\begin{array}{l}\text { Area } \\
\text { ha }\end{array}$} & \multirow[t]{2}{*}{ Yield ( $\mathrm{t})$} & \multirow{2}{*}{$\begin{array}{l}\text { Sale price } \\
\text { /t (Rs) }\end{array}$} & \multirow{2}{*}{$\begin{array}{l}\text { Cost of } \\
\text { Cultivation (Rs) }\end{array}$} & \multicolumn{2}{|c|}{ Returns (Rs) } \\
\hline & & & & & Gross & Net \\
\hline \multicolumn{7}{|c|}{ Integrated Farming System Unit } \\
\hline \multicolumn{7}{|c|}{ Field crops } \\
\hline Kharif-Rice & \multirow[t]{3}{*}{0.24} & 1.6 & 15000 & 6000 & 24000 & 18,000 \\
\hline Rabi-Sweet corn & & 18,000 cobs & $3 / \mathrm{cob}$ & 24000 & 54000 & 30,000 \\
\hline Summer- Dhaincha & & Ploughed in situ & & & & \\
\hline Fruit crop - Banana & 0.15 & 11.5 & 5000 & 16600 & 57500 & 40900 \\
\hline \multicolumn{7}{|l|}{ Vegetable crops } \\
\hline Kharif-Brinjal & \multirow[t]{2}{*}{0.2} & 2.0 & 12000 & 10,000 & 24,000 & 14,000 \\
\hline Rabi - Tomato & & 2.0 & 20,000 & 20,000 & 40,000 & 20,000 \\
\hline \multicolumn{7}{|l|}{ Others } \\
\hline Coconuts & Bunds & 2,500 nuts & 10 per nut & $8,500^{*}$ & $25,000 *$ & $16,500 *$ \\
\hline Field beans & Bunds & 0.6 & 30000 & 3,000 & 18,000 & 15,000 \\
\hline Bottle gourd & 0.04 & 200 fruits & $10 /$ fruit & 500 & 2,000 & 1,500 \\
\hline Bitter gourd & & 0.165 & 30,000 & 1,000 & 4,950 & 3,950 \\
\hline Drumstick & 20 plants & 400 pods & 2/pod & - & 800 & 800 \\
\hline Total & 1.76 & & & 89600 & 250250 & 160650 \\
\hline \multicolumn{7}{|l|}{ Fodder production } \\
\hline \multicolumn{7}{|c|}{ Annual crops (Roughages) } \\
\hline Rice straw & 0.24 & 2.0 Hay & & & & \\
\hline Sweet corn stover & 0.24 & $\begin{array}{l}6.0 \text { moist } \\
(2 t \text { dry) }\end{array}$ & & & & \\
\hline $\begin{array}{l}\text { Fodder Jowar Green- } \\
\text { kharif and rabi }\end{array}$ & 0.06 & $4.0+3.0$ & & & & \\
\hline $\begin{array}{l}\text { Fodder maize Green- } \\
\text { kharif and rabi }\end{array}$ & 0.06 & $4.0+3.0$ & & & & \\
\hline \multicolumn{7}{|l|}{ Perennial crops } \\
\hline \multicolumn{7}{|l|}{$\begin{array}{l}\text { Hybrid Napier green } \\
\text { grass (Roughage) }\end{array}$} \\
\hline Variety Co 4 & 0.06 & 12.0 & & & & \\
\hline Variety Co 5 & 0.06 & 12.0 & & & & \\
\hline \multicolumn{7}{|l|}{ Legumes } \\
\hline Lucerne & 0.12 & 20 & & & & \\
\hline \multicolumn{7}{|c|}{ Conventional cropping system } \\
\hline Kharif-Rice & 1.0 & 7.23 & 15000 & 55350 & 108450 & 53100 \\
\hline \multirow[t]{2}{*}{ Rabi- Maize } & 1.0 & 8.18 & 13500 & 25157 & 110430 & 85273 \\
\hline & & & & 80507 & 218880 & 138373 \\
\hline
\end{tabular}

Note: Income from coconut will commence after 3 years* 
Table. 2 Cost of production and income from livestock

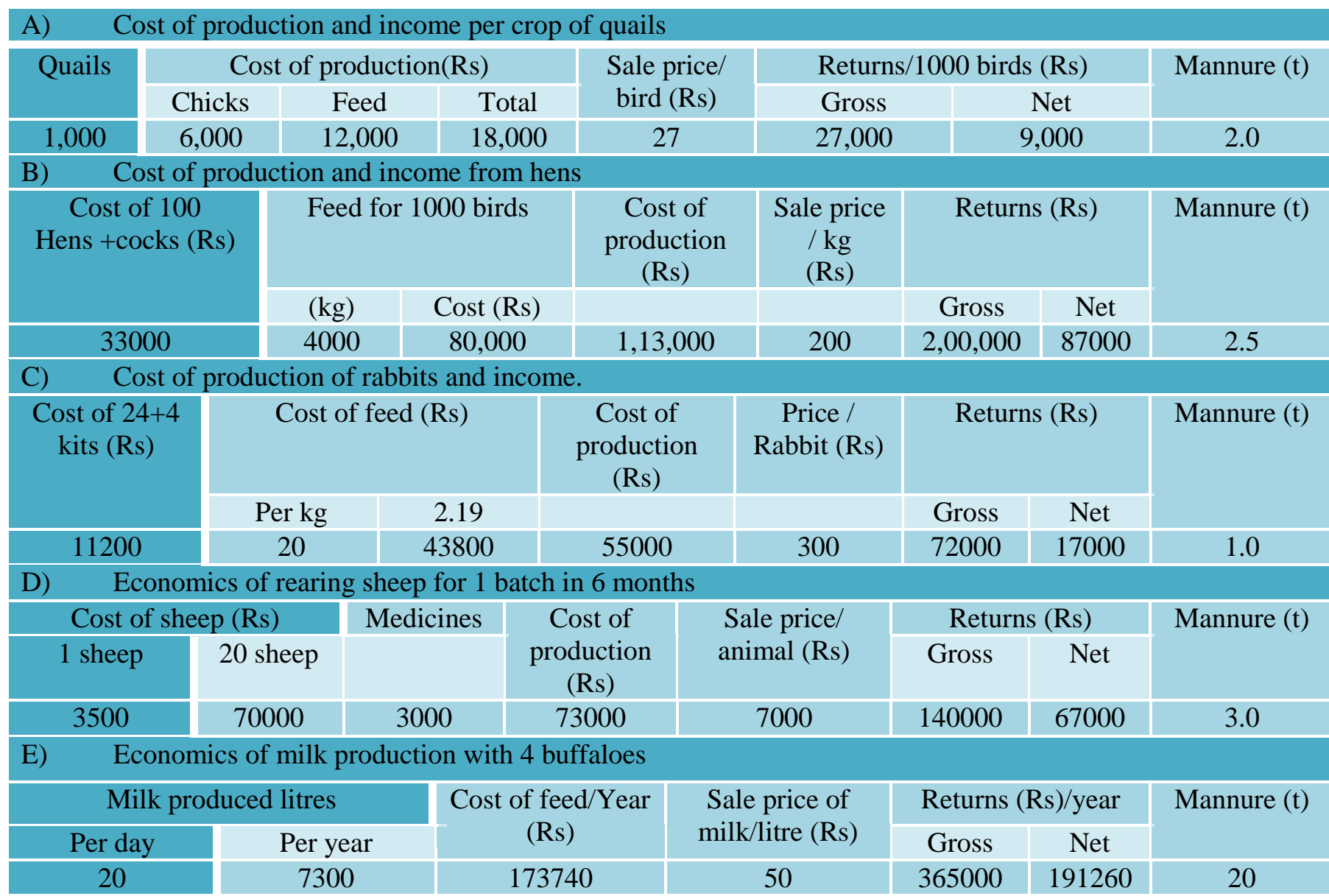

Table.3 Cost of production and income from the components of IFS unit and conventional system

\begin{tabular}{|c|c|c|c|c|}
\hline \multirow[t]{2}{*}{ S. No. } & \multirow[t]{2}{*}{ Component } & \multirow[t]{2}{*}{ Cost of production (Rs) } & \multicolumn{2}{|c|}{ Returns (Rs) } \\
\hline & & & Gross & Net \\
\hline \multicolumn{5}{|c|}{ Integrated Farming System } \\
\hline 1 & Crops & $89,600.00$ & $2,50,250.00$ & $1,60,650.00$ \\
\hline 2 & Dairy & $1,73,740.00$ & $3,65,000.00$ & $1.91,260.00$ \\
\hline 3 & Sheep & $73,000.00$ & $1,40,000.00$ & $67,000.00$ \\
\hline 4 & Rabbits & $55,000.00$ & $72,000.00$ & $17,000.00$ \\
\hline 5 & Hens & $1,13,000.00$ & $2,00,000.00$ & $87,000.00$ \\
\hline 6 & Quails & $1,44,000.00$ & $21,6000.00$ & $72,000.00$ \\
\hline 7 & Manure & & & $14,250.00$ \\
\hline & Total Rs. & $6,48,340.00$ & $12,43,250.00$ & $6,09,160.00$ \\
\hline \multicolumn{5}{|c|}{ Conventional system (Rice-Maize) } \\
\hline 8 & Rice & 55350 & 108450 & 53100 \\
\hline \multirow[t]{2}{*}{9} & Maize & 25157 & 110430 & 85273 \\
\hline & Total Rs. & 80,507 & $2,18,880$ & $1,38,373$ \\
\hline
\end{tabular}




\section{Rabbits}

The compartment is housed with 24 does female and 4 bucks-males. The body weight reaches $2 \mathrm{~kg}$ in 4-5 months. They were sold @ Rs 150 per kg live weight earning Rs 300 per animal (Table 2). The kittens of rabbit were purchased for Rs 400 each. The cost of 24 does and 4 bucks was Rs 11200 . They eat lot of forages. The females produced 240 kittens. Therefore supplementary feed was fed @ $25 \mathrm{~g}$ to 300 kits equivalent to $6.0 \mathrm{~kg} / \mathrm{day}$. The annual consumption is 2.19 tons. At the rate of Rs $20 / \mathrm{kg}$ the investment was Rs 43800. The cost of production was Rs 55000. The income from 240 rabbits with $2 \mathrm{~kg}$ live weight @ Rs $150 / \mathrm{kg}$ was Rs 72000 . The net profit was Rs 17000.

\section{Sheep}

Ram lambs are the young male sheep. Two batches of 20 ram lambs were maintained during the year. Ram lambs of 3 months age were purchased for Rs.3,500 each, reared for 6 months and then sold at Rs.7,000 each time twice in the year (Table 2). The investment for 2 batches in a year was Rs.73000. The gross income was Rs.140000. The net income was Rs.67000.

\section{Dairy}

Two adults along with the calves were purchased @ 2 lakhs. The 2 adults produced about 10 litres milk each per day during the lactation period of 210 days or 7 months. They are dry as they conceived. Another batch of 2 adults with their calves was purchased for Rs 2 lakhs. Each of these buffaloes is producing 10 litres milk every day (Table 2). The milk is sold at Rs 50 a litre. The green and dry fodder raised in the farm was fed ad libitum. Since murrah buffalo responds to the concentrates additional feed as cotton seed cake and chunni is fed with an expenditure of Rs 1, 73, 740 per year. Still a net profit of Rs 1, 91, 260 was realised from the 2 buffaloes in milk at any time. The calves growing in age are growing in sale price or increase the production of milk if retained. The value for sale of the 2 dry buffaloes also increases.

\section{Manures}

The buffaloes produced 20t, sheep 3.0t, rabbits $1.0 \mathrm{t}$ pellets, quails $2.0 \mathrm{t}$ and hens $2.5 \mathrm{t}$ (Table 2). The total manure was 28.5t. Manure will be applied to the cropped area. The worth of the manure @Rs. 500 per ton is Rs. 14,250 (Table 3). The urine passed from diary and other livestock and shed washes collected in a special pit lined with cement. This is recycled to enrich the soil with nutrients.

An economic evaluation of the model for the expenses and profits from different components in the integrated farming systems over one year is summarised in table 3 for a glimpse. From one ha model earned gross and net returns were Rs 12,43,250 and Rs $6,09,160$ respectively during first year. Out of which, birds contributed major share of 33\% (Rs $4,16,000$ ) followed by $29.3 \%$ of dairy (Rs $3,65,000$ ), $11.2 \%$ of sheep (Rs 1,40,000) and $20 \%$ of crops (Rs 2,50,250) and $5.7 \%$ of rabbits (Rs 72,000). Where as in one ha area of Rice-Maize crop sequence, gross and net returns were Rs 218880 and 138373 respectively. Rice crop realised Rs 108450 and Rs 53100. In maize Rs 110430 and Rs 85273 were earned as gross and net income respectively. IFS unit created additional 550 man days of occupancy as employment generation of from IFS model was 750 man days where as in Rice-Maize system was 225 man days. Some of the concurrent studies of integrated farming systems vs. conventional system are summarised below in agreement with the current findings. 
Integrated farming system approach at ARS, Siruguppa, Karnataka, India recorded 26.3 and 32.3 per cent higher productivity and profitability respectively over conventional rice-rice system.

Among the components evaluated, the highest net returns was obtained from crop $(63.8 \%)$, followed by goat $(30.9 \%)$, fish $(4.0 \%)$ and poultry $(1.3 \%)$, respectively. Employment generation was 275 Man days/ha/year under the integrated farming system (Channabasavanna et al., 2009). Toor et al., (2009), revealed that Integrated farming systems at Kapurthala, involving crops (rice, wheat, and Aloe vera) and livestock (dairy animals, pigs, poultry, fish, rabbits and honey bees), proved more profitable than crops alone (rice-wheat system) and also increased employment generation.

Korikanthimath and Manjunath (2009) at Goa revealed that rice-brinjal crop rotation yielded a total productivity of $11.22 \mathrm{t} / \mathrm{ha}$ rice grain equivalent yield with a net return of Rs.46, 440/ha. Further, with the integration of mushroom and poultry production the system productivity was increased to $21,487 \mathrm{~kg} / \mathrm{ha}$ especially with rice-brinjal rotation leading to an additional returns of Rs 30,865/ha with integration.

In Haryana, Singh et al., (1993) found that in 1 ha area under irrigated conditions of mixed farming with crossbred cows yielded the highest net profit (Rs 20,581/-) followed by mixed farming with buffaloes (Rs 6,218/-) and lowest in arable farming (Rs 4,615/-). Singh et al., (1999) conducted on farm studies in different crop rotations zones of Haryana revealed that maximum returns (Rs/ha) of 12,593, 6,746 and 2,317 were obtained from 1 ha with buffaloes in Rohtak (wheatsugarcane), Hisar (wheat-cotton) and Bhiwani (gram-bajra) respectively. In Tamil Nadu Jayanthi et al., (2001) in their three years study under wet land conditions, revealed that integration of crop with fish, poultry, pigeon, and goat resulted in higher mean economic return of Rs 1,31,118. Integration of enterprises created 576 man days/annum in comparison to 369 man days/year from cropping alone system.

Rangaswami et al., (1995) in their five years study under garden land concluded that mean revenue of Rs. 34600/ ha was realized in one ha of IFS (cropping pattern consists of 1) Cotton + green gram - maize + fodder cowpea- Bellary onion in 0.56 ha, 2) Wheat + sunflower - maize + fodder cowpea- summer cotton + green gram in 0.11 ha 3 ) Grass Bajra Napier (Co. I) in 0.15 ha 4) Lucerne in 0.05 ha and 150 Trees of Leucaena (planted in the bunds) in 0.05 ha. Dairy Unit consists of 3 jersey cows +2 calves, Biogas Unit comprising of $2 \mathrm{~m}^{3}$ capacity and Mushroom Production of $1.5-2.0 \mathrm{~kg} / \mathrm{ha}$.) as compared to RS. 13950 obtained in Conventional Cropping System (cotton + sorghum- finger millet). About $45.5 \mathrm{t}$ of to the animals dung was recycled for the biogas plant. Employment opportunity was also enhanced to the tune of 770 man- days per year under IFS as against conventional cropping.

It is concluded that the integration of livestock-birds-crop components under the network of wells in Telangana is a natural gift to best utilise and recycle the by - products and wastes of each component for the other to increase the production and profits while giving a security of food, fodder, fuel, vegetables and fruits all accessed within the field boundaries of about 1 ha land. It safeguards the soil fertility by the production of surplus manure from different sources. The approach of food and nutritional security through wide range of food items within the farm and economic security improves the livelihood through individual farm holdings. The present model will hold the prosperity of 
the peasants to rid off hunger and the chronic poverty. Thus ultimately ward off debt suicides in the nation.

\section{References}

Channabasavanna, A. S., Biradar, D. P., Prabhudev, K. N. and Mahabhaleswar Hegde. 2009. Development of profitable integrated farming system model for small and medium farmers of Tungabhadra project area of Karnataka. Karnataka $J$. Agric. Sci., 22(1): 25-27.

Faroda, A. S., Yadav, R. S. and Pal, R. N. 1978. Comparative economics of specialized dairy farming, mixed farming and arable farming. J. Res.Har. Agric. Univ., 8: 23439.

Gill, M.S., Samra, J.S., Singh Gurbachan. 2005. Integrated farming system for realizing high productivity under shallow water-table conditions. Research bulletins, Department of Agronomy, PAU, Ludhiana, pp. 1-29.

Jayanthi, C., Rangasamy, A., Mythili, S., Balusamy, M., Chinnusamy, C. and Sankaran, N. 2001. Sustainable productivity and profitability to integrated farming systems in low land farms. In: Extended summaries. National Symposium on Farming System Research on New Millennium., PDCSR, Modipuram. pp. 7981.

Korikanthimath, V.S. and Manjunath, B.L. 2009. Integrated farming systems for sustainability in agricultural production. Indian J Agron., 54(2):140-148.

Rangaswamy, A.; Premsekhar, M. and Venkitaswamy, R. 1995. Ylntegrated. farming system for garden lands. Madras Agricftltural Journal. 82: 6-8, 464-466.
Singh Rajender, Singh Narinder, Phogat, S.B., Sharma, U.K., Singh, R. and Singh, N. 1999.Income and employment potential of different farming system. Haryana Agr Univ J Res., 29(3-4): 143-145.

Singh, C.B., Renkema, J.A., Dhaka, J.P., Singh, Keran and Schiere, J.B. 1993. Income and employment on small farmers. In: Proceeding An International workshop on Feeding of Ruminants on fibrous crop residues: Aspects of treatment, feeding, nutrient evaluation, research and extension. Karnal, Haryana, 4-8 February, 1991, pp. 67-76.

Singh, K. P., Singh, S. N., Kumar, H., Kadian, V. S. and Saxena, K. K. 1993. Economic analysis of different farming systems followed on small and marginal land holdings in Haryana. Haryana J. Agron., 9:122-125.

Singh, S. N., Saxena, K. K., Singh, K. P., Kumar, H. and Kadian, V. S. 1997. Consistency in income and employment generation in various farming systems. Annals of Agril. Res., 18(3): 340-43.

The State of Food Insecurity in the World 2015. Meeting the 2015 international hunger targets: taking stock of uneven progress. FAO, IFAD and WFP. 2015 Rome, FAO.

Tomer, S. P., Sai Ram, R. K., Harika, A. S. and Ganguly, T. K. 1982. Comparative efficiency of dairy and mixed farming systems. Forage Research, 8:93-98.

Toor, M.S., Sidhu, A.S. and Sukhpreet Singh. 2009. Integrated farming systems for income and employment increasing possibilities on small farms in Punjab State. Ministry of Agriculture and Cooperation, Directorate of Economics and Statistics, New Delhi, India, Agricultural Situation in India, 66(9): 519-524.

\section{How to cite this article:}

Goverdhan, M., Md. Latheef Pasha, S. Sridevi and Pragathi Kumari, Ch. 2018. Integrated Farming Approaches for Doubling the Income of Small and Marginal Farmers. Int.J.Curr.Microbiol.App.Sci. 7(03): 3353-3362. doi: https://doi.org/10.20546/ijcmas.2018.703.387 